\title{
APLIKASI ANALISIS LAPORAN KEUANGAN DENGAN METODE ANALISIS RASIO KEUANGAN BERBASIS WEB PADA PT. SINAR GALESONG MANDIRI
}

\author{
Mashud $^{1}$, Herni $^{2}$ \\ Komputerisasi Akuntansi STMIK AKBA ${ }^{1}$, Sistem Informasi STMIK AKBA ${ }^{2}$ \\ Email: mashud@akba.ac.id ${ }^{1}$, ernhy14@mhs.akba.ac.id ${ }^{2}$
}

\begin{abstract}
ABSTRAK
Penelitian ini bertujuan untuk merancang dan mengimplementasikan aplikasi analisis laporan keuangan dengan metode analisis rasio keuangan berbasis web. Analisis rasio keuangan dibagi kedalam beberapa bentuk umum yang sering dipergunakan yaitu: rasio likuiditas, rasio solvabilitas, rasio aktivitas dan rasio profitabilitas. Studi kasus penelitian ini pada PT. Sinar Galesong Mandiri, metode pengumpulan data dengan observasi dan studi literatur. Adapun desain model sistem pada penelitian ini dengan menggunakan UML (Unified Modelling Languange) mencakup use case diagram, class diagram, sequence diagram dan activity diagram. Aplikasi Analisis laporan keuangan ini diharapkan dapat membantu perusahaan untuk mengetahui posisi keuangan perusahaan dalam satu priode, mengetahui keberhasilan dan kelemahan-kelamahan perusahaan serta dapat mengetahui langkah-langkah perbaikan kinerja manajemen perusahaan.
\end{abstract}

Kata Kunci: Aplikasi Berbasis Web, Laporangan Keuangan, Rasio Keuangan,

\section{Pendahuluan}

Era globalisasi di dunia usaha semakin berkembang pesat, dengan banyaknya perusahaan-perusahaan baru yang saling bermunculan, sehingga mendorong perusahaan untuk lebih efisien dan lebih selektif dalam beroperasi sehingga tujuan perusahaan dalam mencapai laba yang tinggi dalam jangka panjang bisa terwujud. Perusahaan sebagai organisasi profit oriented untuk selalu meningkatkan kuantitas serta kualitas usahanya sehingga keuntungan yang diharapkan akan tercapai. Sebagai pihak manajemen dituntut untuk mengantisipasi kondisi seperti ini dengan selalu mengintrospeksi kondisi perusahaan terutama dari segi financialnya, karena hal tersebut memegang kunci hidup matinya perusahaan.

Kondisi perusahaan yang harus selalu dipantau, dapat dilakukan dengan menganalisa laporan keuangan sendiri yang pada umumnya terdiri dari laporan neraca dan laporan laba/rugi. Laporan neraca dan laba/rugi ini bersifat saling berkaitan dan melengkapi. Neraca menggambarkan keadaan keuangan suatu perusahaan pada periode tertentu, sedangkan laporan laba rugi menunjukkan hasil usaha dan biaya-biaya selama periode akuntansi. Laporan keuangan tersebut akan lebih informatif dan bermanfaat, maka pihak-pihak yang berkepentingan terhadap informasi keuangan harus melakukan analisa terlebih dahulu. 
Alat ukur yang digunakan untuk menganalisa laporan keuangan diantaranya adalah analisis rasio keuangan, analisis nilai tambah pasar (Market Value Addedl MVA), Analisis nilai tambah ekonomis (Economic Value Added/ EVA) dan Balance Score Card / BSC, Analisis Capital Asset, Management, Equity, and Liquidity (CAMEL) dan Du Pont System. Metode analisis laporan keuangan yang paling banyak digunakan di Indonesia adalah analisis rasio keuangan. Hal ini dapat dilihat dari penggunaan Indonesian Capital Market Direktory, yang semakin luas sebagai dasar untuk melihat kinerja keuangan perusahaan-perusahaan yang tercatat di Pasar Modal Indoensia.

PT. Sinar Galesong Mandiri (SGM) Makassar adalah salah satu perusahaan Swasta yang bergerak di bidang penjualan kendaraan bermotor pada roda dua. PT. Sinar Galesong Mandiri merupakan salah satu dari ke 44 sub dealer yang membantu memasarkan unit motor merek Suzuki yang juga sekaligus sebagai jaringan bengkel resmi sepeda motor Suzuki. Kondisi keuangan perusahaan tersebut akan dapat diketahui dari neraca, perhitungan sisa hasil usaha (laporan laba rugi). Dari laporan keuangan belum cukup untuk menilai atau mengevaluasi keberhasilan perusahaan. Perusahaan membutuhkan suatu analisa laporan keuangan untuk membantu manager/pemilik.

Dengan adanya aplikasi analisis laporan keuangan ini diharapkan dapat membantu perusahaan untuk mengetahui posisi keuangan perusahaan dalam satu priode, mengetahui keberhasilan dan kelemahan-kelamana perusahaan serta dapat mengetahui langkah-langkah perbaikan kinerja manajemen.

\section{Kerangka Teori}

\subsection{Pengertian Aplikasi}

Aplikasi merupakan program yang berisikan perintah-perintah untuk melakukan pengolahan data. Jadi aplikasi secara umum adalah suatu proses dari cara manual yang ditransformasikan ke komputer dengan membuat sistem atau program agar data diolah lebih berdaya guna secara optimal. [1].

Perangkat lunak/aplikasi adalah suatu subkelas perangkat lunak komputer yang memanfaatkan kemampuan komputer langsung untuk melakukan suatu tugas yang diinginkan pengguna. Biasanya dibandingkan dengan perangkat lunak sistem yang mengintegrasikan berbagai kemampuan komputer, tapi tidak secara langsung menerapkan kemampuan tersebut untuk mengerjakan suatu tugas yang menguntungkan pengguna.

\subsection{Analisis Laporan Keuangan}

Analisis laporan keuangan adalah menguraikan pos-pos laporan keuangan menjadi informasi yang lebih kecil sehingga dapat dipahami dengan tujuan mengetahui kondisi keuangan dalam proses pengambilan keputusan. [2].

Analisis laporan keuangan merupakan alat analisis bagi manajemen keuangan perusahaan yang bersifat menyeluruh, dapat digunakan untuk mendeteksi/mediogsis tingkat kesehatan perusahaan, melalui analisis kondisi arus kas atau kinerja organisasi perusahaan baik yang bersifat parsial maupun kinerja organisasi secara keseluruhan. [3].

\subsection{Laporan Keuangan}

Laporan keuangan adalah suatu informasi yang menggambarkan kondisi keuangan perusahaan, dimana selanjutnya itu akan menjadi suatu informasi yang menggambarkan tentang kinerja suatu 
perusahaan dan sebagaialat untuk berkomunikasi antara data keuangan atau aktivitas suatu perusahaan dengan pihakpihak yang berkepentingan dengan dana atau aktivitas perusahaan tersebut. [4]. sedangkan menurut [5] laporan keuangan merupakan ringkasan dari suatu proses pencatatan dari transaksi-transaksi keuangan yang terjadi selama tahun buku yang bersangkutan.

Pengertian lainnya laporan keuangan adalah laporan tertulis yang memberikan informasi kuantitatif tentang posisi keuangan dan perubahan-perubahannya, serta hasil yang dicapai selama satu periode.[6].

\subsection{Rasio Keuangan.}

Pada dasarnya jumlah analisis rasio banyak sekali, karena rasio dapat dibuat menurut kebutuhan penganalisa. Namun dapat dibagi kedalam beberapa bentuk umum yang sering dipergunakan yaitu: rasio likuiditas, rasio solvabilitas, rasio aktivitas dan rasio profitabilitas.

\section{A. Rasio likuiditas (liquidity ratio)}

Rasio likuiditas merupakan rasio yang digunakan untuk mengukur seberapa likuidnya suatu perusahaan. [7]. Dengan kata lain, rasio likuiditas berguna untuk mengetahui kemampuan perusahaan dalam membiayai dan memenuhi kewajiban pada saat ditagih atau jatuh tempo. Terdapat dua hasil penilaian terhadap pengukuran rasio likuiditas, yaitu apabila perusahaan mampu memenuhi kewajibannya, dikatakan perusahaan tersebut dalam keadaan likuid.Sebaliknya, apabila perusahaan tidak mampu memenuhi kewajiban tersebut, dikatakan perusahaan dalam keadaan illikuid.

Adapun ukuran yang dapat dipakai untuk mengukur likuiditas suatu perusahaan adalah dengan menggunkan rasio-rasio berikut ini:

\section{1) Current ratio}

Current ratio, adalah perbandingan antara aktiva lancar dengan kewajiban jangka pendek (hutang lancar) untuk mengukur seberapa jauh kemampuan aktiva lancar untuk membiayai utang lancar. Rumusnya adalah sebagai berikut:

$$
C R=\frac{\text { Aktiva lancar (currentassets) }}{\text { Utang lancar (currentliabilities) }} \times 100 \%
$$

Semakin besar perbandingan aktiva lancar dengan hutang lancar, semakin tinggi kemampuan perusahaan menutupi kewajiban jangka pendeknya. Apabila rasio lancar 1:1 atau $100 \%$ berarti bahwa aktiva lancar dapat menutupi semua hutang lancar. Jadi dikatakan sehat jika rasionya berada di atas 1 atau diatas $100 \%$. Artinya aktiva lancar harus jauh di atas jumlah hutang lancar.

2) Quick ratio

Quick ratio jauh lebih akurat sebagai alat uji untuk menentukan kemampuan perusahaan untuk memenuhi kewajiban jangka pendek, karena lebih fokus pada aktiva yang sangat likuid dan tidak memperhitumgkan persediaan. Rumusnya adalah sebagai berikut:

$$
Q R=\frac{\text { Aktiva Lancar }- \text { Persediaan }}{\text { Hutang Lancar }} \times 100 \%
$$

Rasio ini menunjukkan kemampuan aktiva lancar yang paling likuid mampu menutupi hutang lancar. Semakin besar rasio ini semakin baik. Angka rasio ini tidak harus $100 \%$ atau 1:1. Walaupun rasionya tidak mencapai 
$100 \%$ tapi mendekati $100 \%$ juga sudah dikatakan sehat

3) Cash ratio

Rasio kas atau cash ratio merupakan alat yang digunakan untuk mengukur seberapa besar uang kas yang tersedia untuk membayar utang. Ketersediaan uang kas dapat ditunjukkan dari tersedianya dana kas atau yang setara dengan kas seperti rekening giro atau tabungan di bank (yang dapat ditarik setiap saat). Rumusnya adalah sebagai berikut:

$$
\text { Cash ratio }=\frac{\text { Cash or Cash equivalent }}{\text { Current liabilities }} \times 100 \%
$$

Rasio ini menunjukkan porsi jumlah kas + setara kas dibandingkan dengan total aktiva lancar. Semakin besar rasionya semakin baik. Sama seperti Quick Ratio, tidak harus mencapai $100 \%$ atau 1:1. Walaupun rasionya tidak mencapai $100 \%$ tapi mendekati $100 \%$ juga sudah dikatakan sehat.

\section{B. Rasio solvabilitas (leverage ratio)}

Rasio solvabilitas atau leverage ratio merupakan rasio yang digunakan untuk mengukur sejauh mana aktiva perusahaan dibiayai dengan utang. Artinya berapa besar beban utang yang ditanggung perusahaan dibanding dengan aktivanya.[7].

Berikut adalah beberapa tujuan dan manfaat perusahaan dengan menggunakan rasio solvabilitas adalah untuk menilai dan mengetahui kemampuan posisi perusahaan terhadap kewajiban terhadap pihak lainnya, mengetahui kemampuan perusahaan memenuhi kewajiban yang bersifat tetap, menilai dan mengetahui keseimbangan antara nilai aktiva khususnya aktiva tetap dan modal, untuk menilai seberapa besar aktiva perusahaan dibiayai oleh utang, mengetahui seberapa besar utang perusahaan berpengaruh terhadap pengelolaan aktiva, menilai berapa bagian dari setiap modal sendiri yang dijadikan jaminan utang jangka panjang.

Ada beberapa jenis rasio solvabilitas yang sering digunakan adalah sebagai berikut:

\section{1) Debt to asset ratio}

Debt ratio merupakan rasio utang yang digunakan untuk mengukur perbandingan antara total utang dengan total aktiva. Dengan kata lain, seberapa besar aktiva perusahaan dibiayai oleh utang atau seberapa besar utang perusahaan berpengaruh terhadap pengelolaan aktiva. Dari hasil pengukuran, apabila rasionya tinggi, artinya pendanaan dengan utang semakin banyak, maka semakin sulit bagi perusahaan untuk memperoleh tambahan pinjaman karena dikhawatirkan perusahaan tidak mampu menutupi utang-utangnya dengan aktiva yang dimilikinya. Untuk mengukur besarnya rasio hutang ini digunakan rumus:

Debt ratio $=\frac{\text { Total Hutang }(\text { totaldebt })}{\text { Total Aktiva }(\text { totalassets })} \times 100 \%$

Apabila debt ratio dibawah 1:1 atau $100 \%$ berarti bahwa debt ratio baik dan semakin kecil semakin baik.

\section{2) Debt to equity ratio}

Rasio hutang dengan modal sendiri (debt to equity ratio) adalah imbangan antara hutang yang 
dimiliki perusahaan dengan modal sendiri. Semakin tinggi rasio ini berarti modal sendiri semakin sedikit dibanding dengan hutangnya. Bagi perusahaan sebaiknya, besarnya hutang tidak boleh melebihi modal sendiri agar beban tetapnya tidak terlalu tinggi.

$$
\text { Debt equityratio }=\frac{\text { total utang }(\text { debt })}{\text { ekuitas }(\text { equity })} \times 100 \%
$$

Apabila debt equity dibawah 1:1 atau $100 \%$ berarti debt equity baik dan semakin kecil semakin baik.

\section{3) Long Term Debt to Equity Ratio (LTDtER)}

Long term debt to equity ratio merupakan rasio antara utang jangka panjang dengan modal sendiri. Tujuannya adalah untuk mengukur berapa bagian dari setiap rupiah modal sendiri yang dijadikan jaminan utang jangka panjang dengan cara membandingkan antara utang jangka panjang dengan modal sendiri yang disediakan oleh perusahaan.

Rumusan untuk mencari long term debt to equity ratio adalah dengan menggunakan perbandingan antara uatang jangka panjang dengan modal sendiri, yaitu:

$$
\mathrm{LTDtER}=\frac{\text { long term debt }}{\text { equity }} \times 100 \%
$$

Apabila debt equity dibawah 1:1 atau $100 \%$ berarti debt equity baik dan semakin kecil semakin baik.

\section{Rasio Aktivitas (activity ratio)}

Ratio Aktivitas merupakan rasio yang digunakan untuk mengukur efektivitas perusahaan dalam menggunakan aktiva yang dimilikinya. Atau dapat pula dikatakan rasio ini digunakan untuk mengukur tingkat efesiensi (efektivitas) pemanfaatan sumber daya perusahaan.

Dari hasil pengukuran ini, akan diketahui sebagai hal yang berkaitan dengan aktivitas perusahaan sehingga manajemen dapat mengukur kinerja mereka selama ini.

1) Perputaran Sediaan (Inventory Turn Over)

Perputaran sediaan merupakan rasio yang digunakan untuk mengukur berapa kali dans yang ditanam dalam sediaan (inventory) ini berputar dalam satu periode. Dapat diartikan pula bahwa perputaran sediaan merupakan rasio yang menunjukkan berapa kali jumlah barang sediaan diganti dalam satu tahun. Semakin kecil rasio ini, semakin jelek demikian pula sebaliknya. Rumusan untuk mencari inventory turn over dapat digunakan cara sebagai berikut:

Inventory turn over $=\frac{\text { Harga pokok barang yang dijual }}{\text { Sediaan }}$

Apabila inventory turn over diatas $1: 1$ atau $100 \%$ berarti inventory turn over baik dan semakin tinggi semakin baik.

2) Perputran Modal Kerja ( Working Capital Turn Over)

Perputaran modal kerja atau working capital turn over merupakan salah satu untuk mengukur atau menilai keefektifan modal kerja perusahaan selam 
periode tertentu. Artinya seberapa banyak modal kerja berputar selama satu periode. Untuk mengukur rasio ini, kita membandingkan antara penjualan dengan modal kerja. Rumus yang digunakan untuk mencari perputaran modal kerja adalah sebagai berikut :

Perputaran modal kerja $=\frac{\text { Penjualanbersih }}{\text { Modalkerjarata }- \text { rata }}$

Apabila perputaran modal kerja diatas $1: 1$ atau $100 \%$ berarti perputaran modal kerja baik dan semakin tinggi semakin baik.

3) Perputaran aktiva tetap (Fixed Assets Turn Over)

Fixed assets turn over merupakan rasio yang digunakan untuk mengukur berapa kali dana yang ditanamkan dalam aktiva tetap berputar dalam satu periode. Atau dengan kata lain, untuk mengukur apakah perusahaan sudah menggunakan kapasitas aktiva tetap sepenuhnya atau belum. Untuk mencari rasio ini, caranya adalah membandingkan antara penjualan bersih dengan aktiva tetap dalam suatu periode. Rumusan untuk mencari fixed assets turn over dapat digunakan sebagai berikut :

FATO $=\frac{\text { Penjualan }(\text { sales })}{\text { Total aktiva tetap }(\text { Total fixed assets })}$

Apabila fixed assets turn over diatas 1:1 atau $100 \%$ berarti fixed assets turn over baik dan semakin tinggi semakin baik.
4) Perputaran total aktiva (Total Assets Turn Over)

Rasio yang terakhir untuk komponen rasio aktivitas adalah rasio perputaran total aktiva. Sama seperti halnya rasio perputaran aktiva tetap, rasio ini menghitung efektivitas penggunaan total aktiva. Rasio yang tinggi biasanya menunjukkan manajemen yang baik, sebaliknya rasio yang rendah harus membuat manajemen mengevaluasi strategi, pemasarannya, dan pengeluaran investasi atau modalnya. Rumus untuk mencari Total Assets Turn Over adalah sebagai berikut.

$$
\text { Total assets turn over }=\frac{\text { Penjualan }(\text { sales })}{\text { Total aktiva }}
$$

Apabila Total Assets Turn Over diatas 1:1 atau $100 \%$ berarti Total Assets Turn Over baik dan semakin tinggi semakin baik.

\section{Rasio profitabilitas (profitability ratio)}

Rasio profitabilitas merupakan rasio untuk menilai kemampuan perusahaah dalam mencari keuntungan. Rasio ini juga memberikan ukuran tingkat efektivitas manajemen suatu perusahaan. Hal ini ditunjukkan oleh laba yang dihasilkan dari penjualan dan pendapatan investasi.

Hasil dari perhitungan rasio ini dapat dijadikan alat evaluasi kinerja manajemen selama ini, apakah mereka telah bekerja secara efektif atau tidak. Jika berhasil mencapai target yang telah ditentukan, mereka telah dikatakan berhasil mencapai target untuk periode atau beberapa periode. 
1) Profit margin on sales

Rasio ini menghitung sejauh mana kemampuan perusahaan menghasilkan laba bersih pada tingkat penjualan tertentu. Rasio ini bisa dilihat langsung pada analisis common size untuk laporan rugi laba (baris paling akhir). Rasio ini bisa diintepretasikan juga sebagai kemampuan perusahaan menekan biaya-biaya (ukuran efisiensi) di perusahaan pada periode tertentu rumus untuk mencari profit margin, yaitu sebgai berikut.

$$
\text { profit margin }=\frac{\text { LabaBersih }}{\text { Penjualan }}
$$

Apabila Profit margin on sales diatas 1:1 atau $100 \%$ berarti Profit margin on sales baik dan semakin tinggi semakin baik karena dianggap kemampuan perusahaan dalam mendapatkan laba cukup tinggi

2) Hasil Pengembalian Investasi (ROI)

Hasil pengembalian investasi atau llebih dikenal dengan nama Retur on Investment (ROI) merupakan rasio yang menunjukkan hasil (return) atas jumlah aktitiva yang digunakan dalam perusahaan. ROI juga merupakan suatu ukuran tentang efektivitas manajemen dalam mengelolah investasinya. Disamping itu, hasil pengembalian investasi me unjukkan produktivitas dari seluruh dana perusahaan, baik modal pinjaman maupun modal sendiri. Semakin kecil (rendah) rasio ini, semakin kurang baik, demikian pula sebaliknya. Rumus untuk mencari retur on investment dapat digunakan sebagai berikut.

$R O I=\frac{\text { Earning after interest and tax }}{\text { total assets }} \times 100 \%$

Apabila $R O I$ diatas 1:1 atau $100 \%$ berarti $R O I$ baik dan semakin tinggi semakin baik

3) Hasil Pengembalian Ekuitas Return on equity (ROE)

Hasil pengembalian ekuitas atau return on equity merupakan rasio untuk mengukur laba bersih sesudah pajak dengan modal sendiri. Rasio ini menunjukkan efesiensi penggunaan modal sendiri. Semakin tinggi rasio ini, semakin baik. Artinya posisi pemilik perusahaan semakin kuat, demikian pula sebaliknya. Rumus untuk mencari

$$
R O E=\frac{\text { earningafterinterestandtax }}{\text { equity }} \times 100 \%
$$

Apabila ROE diatas 1:1 atau $100 \%$ berarti ROE baik dan semakin tinggi semakin baik

\section{Metodologi Penelitian}

\subsection{Metode Pengumpulan Data}

Metode pengumpulan data yang digunakan dalam penelitian ini adalah sebagai berikut:

A. Observasi

Observasi adalah pengamatan langsung terhadap suatu kegiatan yang sedang dilakukan. Tahap ini dilakukan dengan turun langsung ke lapangan untuk melakukan pengambilan data di PT. Sinar Galesong Mandiri.

B. Studi Literatur

Metode ini dilaksanakan dengan melakukan studi kepustakaan melalui 
membaca buku-buku maupun artikelartikel yang dapat mendukung penelitian ini.

\subsection{Desain Model Sistem}

Adapun desain model sistem pada penelitian ini dengan menggunakan UML (Unified Modelling Languange) mencakup use case diagram, class diagram, sequence diagram dan activity diagram

\section{A. Use Case Diagram}

Dalam use case admin ini menjelaskan tentang tahapan yang dapat dilakukan oleh admin antara lain menampilkan Master Data Akun, menginput Transaksi Jurnal, menampilkan laporan, dan menampilkan Rasio dapat dilihat pada gambar 1 .

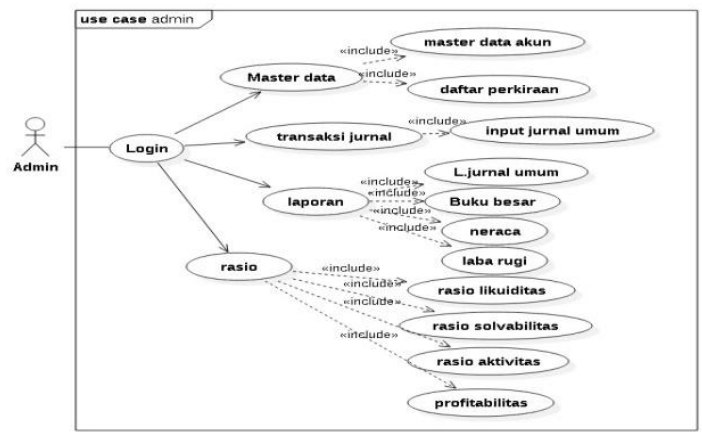

Gambar 1: Use Case Diagram Admin

\section{B. Sequence Diagram}

Sequence diagram menggambarkan secara umum tahap demi tahap interaksi yang terjadi dengan user.

1) Master data

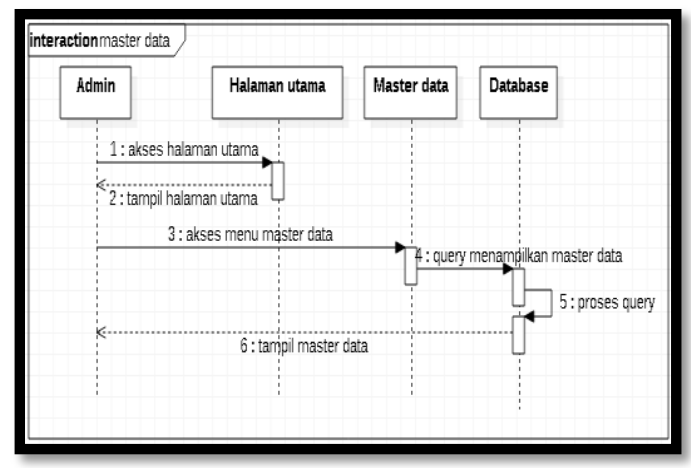

Gambar 2: Sequence Master Data
2) Analisis Laporan Keuangan

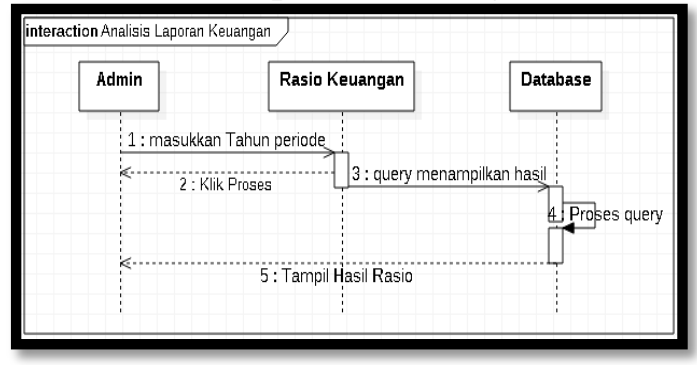

Gambar 2: Sequence Analisis

Laporan Keuangan

\section{Activity Diagram}

Activity diagram yang menggambarkan aktivitas di dalam sistem yang berjalan.

1) Master data akun

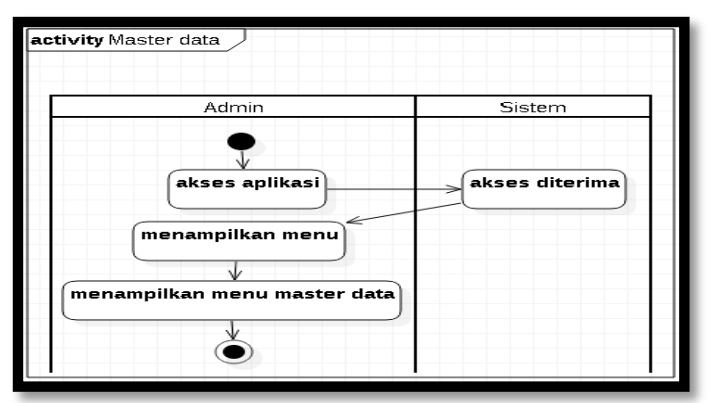

Gambar 4: Activity Master Data Akun

2) Analisis Laporan Keuangan

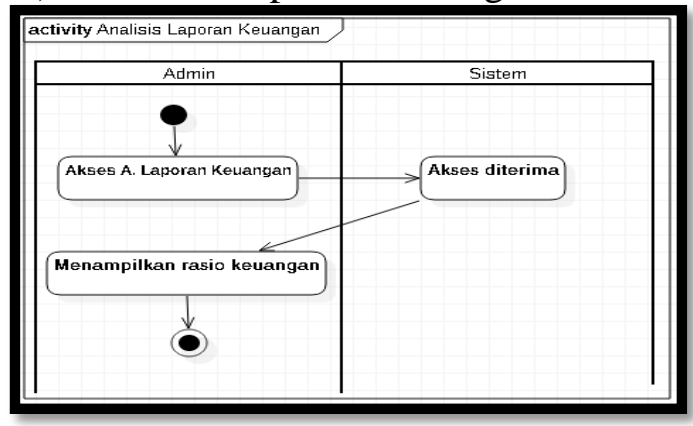

Gambar 5: Activity Analisis Laporan Keuangan

\section{Hasil Rancangan Aplikasi}

A. Form login

Halaman Login ialah halaman yang pertama kali muncul dan harus diisi dengan username dan passwoard sebelum 
masuk ke menu utama. Halaman Login terlihat pada gambar 6 berikut :

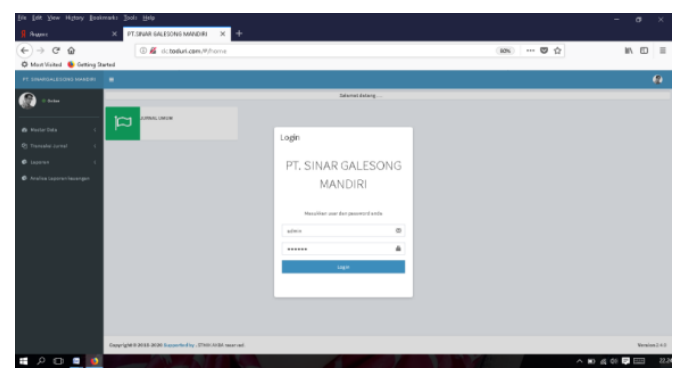

Gambar 6: Form Login

B. Master Data Akun

Pada awal proses dilakukan penginputan master akun yang akan nantinya terdapat dilaporan neraca dan laba/rugi. Menu data akun yang terlihat pada gambar 7 merupakan menu yang akan menampilkan semua data yang tardapat pada neraca dan laba/rugi.

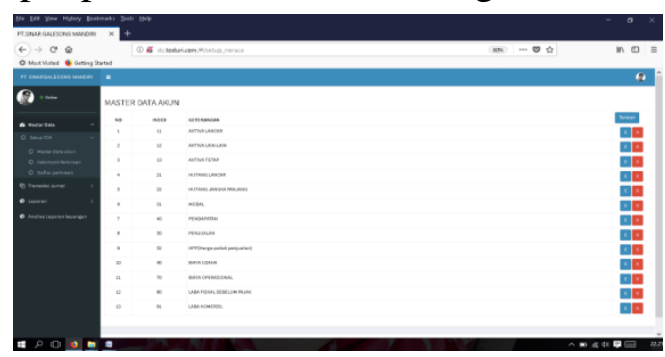

Gambar 7: Form Master Data Akun

C. Hasil Analisis Laporan Keuangan

Hasil analisis laporan keuangan menampilkan hasil analisis rasio keuangan perusahaan. Hasil analisis laporan keuangan perusahaan seperti pada gambar 8 berikut :

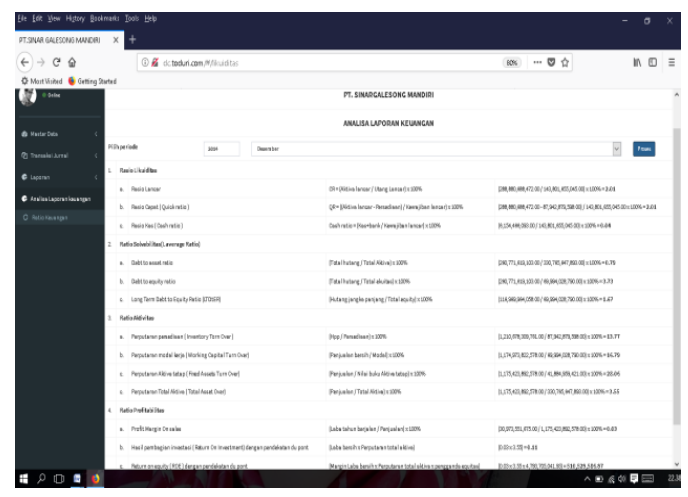

Gambar 8: Hasil Analisis Laporan Keuangan

\section{Kesimpulan dan Saran}

\subsection{Kesimpulan}

Dengan adanya Aplikasi Analisis laporan keuangan ini diharapkan dapat membantu PT. Sinar Gaelsong Mandiri untuk mengetahui posisi keuangan perusahaan dalam satu priode, mengetahui keberhasilan dan kelemahan-kelamahan perusahaan serta dapat mengetahui langkahlangkah perbaikan kinerja manajemen perusahaan.

\subsection{Saran}

Saran yang diharapkan yaitu adanya pelatihan sumber daya manusia sehingga dapat mengoperasikan aplikasi ini dan ada pengembangan dari aplikasi terintegrasi yang dapat mendukung kegiatan perusahaan.

\section{DAFTAR PUSTAKA}

[1]. Jogiyanto, H. M. (2005). Pengenalan Komputer. Andi : Yogyakarta

[2]. Harahap, S. S. (2008). Analisis Kritis Atas Laporan Keuangan. Esisi Ketujuh. P T. Rajagrafindo Persada. Jakarta

[3]. Harmono, (2009), Manajemen Keuangan Berbasis Balanced Scorecard (Pendekatan Teori, Kasus, dan Riset Bisnis), Bumi Aksara, Jakarta.

[4]. Fahmi, I. (2014). Analisis Kinerja Keuangan. Edisi ketiga. Alfabeta. Bandung

[5]. Baridwan, Z. (2004). Intemediate Accounting.Edisi kedelapan. BPFE. Yogyakarta

[6]. Sadeli. (2006). Dasar-Dasar Akuntansi. Edisi ketiga. Bumi Aksara. Jakarta.

[7]. Kasmir, S. (2010). Analisis Laporan Keuangan. Edisi ketiga. PT. Rajagrafindo Persada. Jakarta. 